\title{
KOMUNIKASI NEGOSIASI INDIVIDU GAY DALAM MEMUTUSKAN VCT SECARA SUKARELA
}

\author{
Sheila Lestari Giza Pudrianisa \\ Magister Ilmu Komunikasi Universitas Diponegoro, Semarang \\ gizagizo@gmail.com
}

\begin{abstract}
Abstrak
Penelitian ini bertujuan untuk memahami proses komunikasi negosiasi individu gay memutuskan VCT (Voluntary, Counseling and Tasting) serta pendampingan secara sukarela. Informan penelitian adalah LSL yang tergabung dalam Semarang GAY@ Community yang terdiri atas tiga orang LSL negatif dan tiga orang LSL positif. Keluarga, teman dan pacar sesama LSL berpengaruh pada pengambilan keputusan saat proses negosiasi berjalan. Proses komunikasi negosiasi menggunakan tiga pendekatan yaitu framing sebagai posisi tawar, penyusunan pesan sebagai elemen dalam membentuk pesan persuasi, dan mengelola hubungan antara LSL dengan Dinas Kesehatan yang menyediakan layanan tes gratis dan layanan konseling (VCT) rutin, yang ditandai dengan perjanjian tertulis atau penandatangan kontrak sebagai bentuk kesepakatan antara negosiator (petugas kesehatan) dengan narasumber. Penelitian ini menghasilkan sikap sukarela karena terdorong rasa tanggung jawab terhadap diri sendiri dengan konsep komunikasi negosiasi berulang (multilayer negotiation) menggunakan gaya komunikasi yang berbeda yaitu karena paksaan, imbalan serta rasa penasaran.
\end{abstract}

Kata kunci: Negosiasi berulang, LSL, VCT, ODHA

\begin{abstract}
This research has purpose to understand a process communication of negotiation guy individuals decide on VCT (Voluntary, Counseling and Tasting) as well as voluntary colleague. The research information were MSM who joined in Semarang GAY@ community consists that of three persons negative and three persons positive include family,friends, girl or boy friend of MSM has an effect decision when during negotiation process. The process negotation uses three approachs such as framing become undisturbed position,composing massage become element and then massage transform persuasi, and can make relationship between MSM and public health office that provide service free test and conseling services (VCT), as indicated by a agreement or sign contract as a form of agreement between the negotiator (health worker) and the resource persen. This research can produce a voluntary attitude inasmuch as it shoved a sense of responsibility towards oneself with concept repeatation negotiation communication (multilayer negotiation) can use different communication such as compulsion, wage, and curious.
\end{abstract}

Keywoards: Multilayer negotiation, MSM, VCT, ODHA. 


\section{Pendahuluan}

Virus HIV/AIDS merupakan penyakit mematikan yang jumlah penderitanya semakin meningkat dari tahun ke tahun. Tidak hanya di kota-kota besar, penyebaran virus HIV/AIDS kian menjamah di berbagai pelosok daerah. Berbagai cara dan pencegahanpun telah diupayakan Dinas Kesehatan serta lembaga-lembaga terkait, namun tetap saja penyakit HIV/AIDS masih berada pada titik tertinggi untuk penyakit mematikan.

Mereka yang memiliki usia dibawah 25 tahun, lebih rentan terhadap penyebaran virus HIV/AIDS dengan rentang setiap 25 menit terdapat satu orang terinfeksi virus HIV/AIDS. Data dari KPAI dalam laporan Kementerian Kesehatan Triwulan III, sepanjang Januari 2012 sampai dengan September 2012 melaporkan ada 15.372 kasus HIV dan 3.541 kasus AIDS dengan total angka kumulatif sebanyak 39.434 kasus di seluruh Indonesia. Ada berbagai faktor yang menyebabkan penularan virus HIV/AIDS diantaranya penggunaan alat-alat kedokteran yang tidak higienis, penggunaan jarum suntik bersama bagi pengguna obat-obatan terlarang (NAPZA), penularan dari ibu ke bayi yang dikandung, saat proses persalinan dan menyusui serta penularan paling cepat melalui hubungan seksual sebanyak $95 \%$ yang dilakukan oleh teman hetero $65 \%$ dan hubungan teman sejenis $30 \%$. Tahun 2012 , rasio kasus pada kategori jenis kelamin memiliki perbandingan 1:1, sementara untuk kasus AIDS rasio antara laki-laki dan perempuan 2:1. Peningkatan penderita kasus HIV/AIDS tertinggi didominasi oleh kelompok umur 20-29 tahun dan disusul oleh kelompok umur 30-39 tahun yang artinya penderita HIV/ AIDS lebih banyak tertular pada mereka yang memiliki usia produktif lebih muda (Diunduh dari Sanusi, 2014. Mobilitas Penduduk Usia Produktif dan Penyebaran HIV/ AIDS di Inodnesia Tahun 2013. Direktorat Analisis Dampak Kependudukan, BKBN pada 10 Juli 2016 pukul 15.06 WIB).

Peningkatan Orang Dengan HIV/AIDS (ODHA) juga terjadi di Kota Semarang. Jumlah angka kumulatif penderita HIV/AIDS di Kota Semarang terbanyak dialami oleh laki-laki dengan prosentase sebesar $56 \%$ sedangkan perempuan sebanyak $44 \%$. Peningkatan tersebut meningkat dari tahun ke tahun dan salah satu penyumbang virus tersebut adalah pasangan homoseksual (LSL). Hal tersebut dintunjukkan dengan data yang diperoleh dari Dinas Kesehatan Kota Semarang. Tahun 2007 yang semula tidak ditemukan adanya penderita HIV, mengalami peningkatan hingga tahun 2016 dengan jumlah 44 orang.

Secara kumulatif, sejak 1995 hingga Juni 2016 terdapat 20.782 kasus HIV di Kota Semarang dengan penemuan kasus tertinggi pada tahun sebanyak 520 kasus. Untuk AIDS, data secara kumulatif pada 1998 hingga Juni 2016, terdapat 3032 kasus dengan total 67 ODHA akhirnya meninggal dunia. Melihat dari kategori, penularan virus AIDS tertinggi pada temuan lapangan merujuk pada hubungan heteroseksual dengan jumlah 78\%, disusul oleh kategori LSL dengan temuan hubungan homoseksual sebesar $7 \%$ dan biseksual 3\%. Penggunaan suntikan bersama pada pemakai obat-obatan terlarang (NAPZA) menunjukkan temuan sebesar 5\%. 
Temuan kasus AIDS terendah pada kategori penggunaan alat-alat medis yang tidak higienis sebesar $1 \%$. Dari data yang ditampilkan pada table diatas, kategori LSL menyumbang penularan virus AIDS pada urutan kedua. Tidak dapat dipungkiri, maraknya hubungan sejenis membuat penyebaran HIV/AIDS kian cepat yang disebabkan karena maraknya transaksi seks kategori LSL yang kian digandrungi oleh remaja masa kini. Melihat dari jumlah kasus HIV/AIDS yang ditemukan secara kumulatif di Kota Semarang terus meningkat, meskipun jumlah ODHA yang mau terbuka mengalami perbedaan, hal tersebut diibaratkan seperti fenomena gunung es, karena jumlah kasus yang ketahuan hanya 20 persen dari total kasus secara keseluruhan.

Tidak hanya data yang diperoleh dari Dinas Kesehatan Kota Semarang, berbagai media juga menyoroti isu penyebaran HIV/AIDS yang salah satunya disebabkan oleh kategori LSL yang membentuk opini dan stigma di masyarakat. Dari beberapa pemberitaan penulis mencoba merangkumnya. Data terbaru dari KPA Jateng, jumlah kasus HIV dan AIDS komulatif Jateng hingga bulan September 2015 adalah 12.814 dengan rincian HIV sebanyak 6.945 dan AIDS 5.869 dan yang meninggal 1188. Dari jumlah tersebut usia 25 hingga 29 menjadi kelompok umur yang paling banyak terinfeksi. Data yang diperoleh tersebut membuat Komisi Penanggulangan AIDS (KPA) Jateng berupaya mengajak remaja tingkat SMA dan SMK untuk ikut mencegah dalam penanggulangan bahaya HIV/AIDS melalui berbagai penguluhan dan kampanye (Diunduh dari http://jateng.tribunnews.com/2016/01/15/remaja-menjadipopulasi-tertinggi-hivaids-jateng diunduh pada 15 Sepetember 2016 pukul 14. 22 penulis Rival Almanaf diunggah 15 Januari 2015).

Data terbaru dari Dinas Kesehatan Kota Semarang yang ditulis ulang oleh Suara Merdeka, menjelaskan bahwa penyebaran virus mematikan HIV/AIDS di Kota Semarang sepanjang tahun 2016 yang ditemukan ada 76 kasus di 16 Kecamatan. Selain itu, ketua Semarang GAY@ Community (SGC) juga menuturkan bahwa penderita HIV/AIDS kategori LSL sepanjang 2011 hingga Juni 2016 yang ditemukan ada 229 orang. (Dikutip dari Suara Merdeka, terbit pada Kamis Wage 6 Oktober 2016 rubrik "telisik" halaman 19, Tim penulis Zakki Amali, Muhammad Syukron, Royce Wijaya, Modesta Fiska).

Melihat keprihatinan akibat peningkatan HIV/AIDS yang terjadi, maka SGC membantu Dinas Kesehatan Kota Semarang berusaha untuk melakukan berbagai upaya dalam memberikan penyuluhan, pencegah bagi anggota di komunitas tersebut yang belum terkena HIV/AIDS untuk melakukan VCT (Voluntery Conseling and Test) serta mereka yang terkena HIV/AIDS untuk mau didampingi dalam upaya mengembalikan mental diri agar lebih semangat menjalani hidup.

Berbagai cara tentu dilakukan mereka dalam upaya mensosialisasikan serta mengkampanyekan tes kesehatan atau VCT bagi anggota komunitas tersebut dan masyarakat. Dalam proses mengkomunikasikan, tidak sedikit adanya kendala serta hambatan berkomunikasi karena adanya beban berganda karena stigma berganda yang dimunculkan masyarakat yaitu 
"sudah homoseksual" juga "menderita HIV/AIDS". Beban dan stigma tersebut yang menjadikan ketakutan dan hambatan terbesar untuk melakukan tes, konseling maupun bagi ODHA untuk mau melakukan pendampingan.

Agar pembahasan dapat diuraikan lebih dalam dan tidak meluas, maka permasalahan yang diambil dalam penelitian adalah bagaimana proses komunikasi negosiasi dalam pengambilan keputusan yang membuat individu gay atau LSL mau melakukan VCT secara sukarela pada Semarang GAY@ Community.

Kajian empirik hasil penelitian sebelumnya adalah penelitian dari Victoria Katherine Dale Blackwell dan Hardie yang berjudul "A qualitative analysis of factors contributing to increased HIV incidence for gay and bisexual men: implications for prevention". Penelitian tersebut fokus pada permasalahan kasus HIV/AIDS yang meningkat pada populasi gay dan biseksual. Pengambilan keputusan untuk seks aman, eksplorasi praktek konseling dengan gay serta biseksual, rekomendasi psikologi dalam pengambilan keputusan serta strategis, validitas dan rekomendasi berdasarkan pengalaman dan opini untuk memberikan kontribusi dalam penanggulangan HIV/AIDS.

Perbedaan pada penelitian sebelumnya yaitu menggunakan teori Self Efficacy dengan fokus pada perubahan perilaku, sedangkan penelitian ini fokus pada proses komunikasi negosiasi dalam upaya untuk melakukan pengambilan keputusan dengan teori negosiasi. Metode kualitatif pada penelitian sebelumnya menggunakan teknik wawancara semi terstrukturuntuk mengumpulkan data yang diperoleh dari narasumber secara langsung, sedangkan pada penelitian ini menggunakan metode kualitatif dengan analisisinterpretasi data dari Van Kaam pada fenomenologi.

Kajian empirik yang kedua adalah hasil penelitian dari Theo Lorenc, Isaac MarreroGuillamo'n, Alexis Llewellyn, Peter Aggleton, Chris Cooper, Angela Lehmann dan Catriona Lindsay yang berjudul "HIV testing among men who have sex with men (MSM): systematic review of qualitative evidence". Penelitian tersebut berfokus pada MSM atau gay tentang layanan yang dituju untuk kelompok, pada mereka yang berhubungan seks dengan tes HIV, serta primer review kualitatif mengenai presepsi atau sikap untuk melakukan tes.

Perbedaan pada penelitian sebelumnya terletak pada teori yang digunakan, mengacu pada strategi jaringan menggunakan persuasi. Sedangkan pada penelitian ini menggunakan teori yang berfokus pada proses komunikasi negosiasi pada pengambilan keputusan dengan menggunakan dua model komunikasi antar pribadi.

Kajian empirik yang ketiga adalah hasil penelitian yang dilakukan Gary. W. Dowsett yang berfokus pada permasalahan bahwa gay dijadikan sasaran utama dalam perkembangan virus HIV/AIDS. Masyarakat juga meyakini bahwa orientasi seksual menyimpang yang dapat mengakibatkan penyebaran HIV/AIDS.Persamaan dari penelitian tersebut adalah menggunakan metode kualitatif dan mengangkat tema pada kaum homoseksual yang distigma oleh 
masyarakat sebagai penyebab utama penyebaran penyakit dengan isu HIV/AIDS. Perbedaan pada penelitian sebelumnya yaitu terletak pada teori yang digunakan. Penelitian sebelumnya menggunakan Teori Jaringan Sosial sebagai pelacak kontak antara laki-laki gay khususnya dalam pengendalian penyakit menular sedangkan pada penelitian ini menggunakan teori pada proses komunikasi negosiasi, serta persuasi.

\section{Tujuan Penelitian}

Berdasarkan latar belakang dan data pada uraian di atas, dapat diketahui bahwa pentingnya memahami negosiasi dalam memutuskan VCT bagi individu Semarang GAY@ Community. Peneliti akan mengungkap proses negosiasi tersebut menjadi penting bagi diri sendiri serta orang-orang di sekitarnya untuk mengatasi hambatan yang ada.

\section{Kerangka Teori}

\subsection{Negotiation theory (Teori negosiasi)}

Merujuk pada penelitian yang dilakukan oleh beberapa peneliti terdahulu, maka pada penelitian ini penulis akan menggunakan teori yang berbeda sebagai eksplorasi akan keragaman teori pada ilmu sosial. Pada penelitian untuk melihat proses komunikasi negosiasi, peneliti menggunakan teori negosiasi sebagai proses awal individu gay sebagai tahap untuk memutuskan keinginannya.

Menurut (Spoelstra and Pienaar, 1996: 3), negosiasi merupakan suatu proses interaksi antara kedua belah pihak dalam melakukan perjanjian yang didasarkan pada kepentingan bersama dengan tujuan menyelesaikan konflik tanpa adanya perdebatan. Negosiasi juga merupakan pertukaran informasi melalui komunikasi. Informasi yang dirumuskan sebagai strategi dan teknik yang berasal dari hubungan negosiasi antara kedua belah pihak dengan tujuan menjalin hubungan atau mengakhiri suatu hubungan. Tujuan pertukaran komunikasi untuk mencapai kesepakatan menggunakan strategi dan teknik yang dimiliki masing-masing pihak yang terkait.

Terdapat beberapa model yang dapat digunakan pada saat negosiasi sedang berlangsung yang dikembangkan untuk membantu negosiator dalam mencapai sebuah kesepakatan. Dalam negosiasi apapun, seorang negosiator yang terapil harus memusatkan perhatiannya pada dua area kunci, yaitu membangun hubungann baik dengan lawan dan memperhatikan kapan lawan negosiasii siap untuk bergerak (Jackman, 2004: 68).

Pada proses komunikasi negosiasi perlu didasarkan pada beberapa jenis kriteria objektif untuk memastikan bahwa semua pihak diperlakukan dengan adil. Hal tersebut dikarenakan untuk mengindari adanya konflik. Terdapat tiga pendekatan agar proses tersebut dapat berjalan sesuai dengan tujuan masing-masing individu, yaitu (1) framing, (2) menyusun strategi, dan (3) mengelola hubungan. Framing adalah perubahan sikap serta menciptakan pengaruh 
yang digunakan untuk memahami situasi dan membuat posisi tawar. Pendekatan psikologis juga digunakan pada framing yang berfungsi sebagai filter persepsi dalam mempengaruhi kegiatan seperti pencarian informasi dan pilihan strategi dan biasanya terletak pada bahasa yang digunakan sebagai negosiasi. Menyusun strategi mengacu pada kinerja komunikatif dan taktik selama negosiasi. Strategi mengacu pada rencana yang luas yang mencakup tindakan, sedangkan taktik adalah pesan khusus yang melakukan gerakan. Sebagai contoh, seorang individu mungkin memiliki strategi integratif yang luas, tetapi pada berbagai titik selama negosiasi mengandalkan taktik distributif untuk mencapainya atau keseluruhan strategi integratifnya. Garis penting dari teori telah difokuskan pada pemodelan strategi yang individu mempekerjakan selama negosiasi. Sebuah model strategi dominan menganggap bahwa proses negosiasi stabil dari waktu ke waktu dan bahwa negosiator konsisten menggunakan baik distributif atau strategi integratif selama negosiasi berlangsung. Mengelola hubungan mengacu pada cara di mana hubungan antara negosiator serta konstituen mereka dikelola. Teori negosiasi membedakan antara agen, konstituen, dan penonton. Negosiator biasanya berfungsi sebagai agen yang mewakili posisi dan kepentingan konstituen tertentu (Littlejohn dan Foss, 2009: 678-679).

Pada penelitian ini, proses negosiasi digunakan sebagai langkah awal dalam mempertimbangkan untuk melakukan suatu tindakan baik di dalam diri maupun dengan orang lain. Negosiasi diperlukan untuk menghindari adanya konflik baik secara lahir maupun batin yang dapat menyebabkan hambatan. Negosiasi disini memiliki manfaat untuk memberikan jawaban dengan cara berkompromi agar tidak terjadi konflik, baik kompromi pada diri sendiri maupun dengan orang lain. Perlu untuk dipahami bahwa, negosiasi juga merupakan suatu cara mencapai sebuah keberhasilan dari suatu tujuan. Tanpa adanya negosiasi, konflik lahir maupun batin akan timbul yang lama-kelamaan akan menjadikan suatu perselisihan serta hambatan baik bagi diri sendiri maupun orang lain. Titik keberhasilan dari suatu negosiasi adalah tercapainya suatu kesepakatan. Kesepakatan tersebut akan ditandai dengan adanya perjanjian diantara keduanya seperti penandatanganan surat persetujuan melakukan tes maupun perjanjian untuk tidak membocorkan semua rahasia pada diri individu. Yang terpenting pada komunikasi negosiasi yang dapat diterapkan dalam penelitian ini berarti tercapainya proses memutuskan serta adanya dorongan bagi individu gay untuk mau melakukan VCT secara sukarela.

\subsection{Persuasion and social influence theories (Teori persuasif dan pengaruh sosial)}

Keberhasilan proses negosiasi sebagai proses awal dalam memutuskan keinginan individu gay tidak terlepas dari adanya pesan persuasi yang dimunculkan sebagai dorongan individu dalam melakukan tes tersebut. Persuasi menjadi penting ketika individu lain di dalam komunitas tersebut berperan aktif, membujuk tanpa adanya pemaksaan dalam melihat keberhasilan dari tujuan untuk melakukan VCT. Semakin berhasil pesan persuasi yang disampaikan, maka 
akan semakin banyak individu gay untuk mau melakukan VCT dengan kesadaran sendiri dan dampak positif dari diterimanya pesan persuasi tersebut akan diteruskan oleh individu lainnya untuk berbagai informasi tersebut. Definisi persuasi sendiri merupakan perubahan sikap akibat paparan informasi dari orang lain.

Menurut Aristoteles, persuasi dapat didasarkan pada sebuah sumber kredibilitas (ethos), emosional (pathos), atau logika (logos). Defines lain mengenai persuasi adalah sebuah proses mempengaruhi orang menggunakan cara yang etis dalam upaya memperkuat masyarakat demokratis serta merupakan bagian inheren dari interaksi sosial. Persuasi bukanlah suatu penipuan yang bergantung pada miskomunikasi, bukan paksaan yang bergantung pada kekuatan yang terletak pad acara berkomunikasi, juga bukan propaganda yang merupakan penghinaan komunikasi, karena persuasif terkait dengan setengah kebenaran dan agenda tersembunyi. Persuasi terutama terkait dengan advokasi atau pendekatan asimetris untuk komunikasi strategis, di mana organisasi menampilkan titik pandang dalam upaya untuk meyakinkan publiknya serta memberikan persetujuan dan dukungan (Smith, 2013: 173)

Dalam proses persuasi, berbagai upaya akan dilakukan oleh individu yang mencoba untuk membujuk individu lain menuju keberhasilan dari tujuan yang ingin dicapai. Keberhasilan yang dimaksud adalah, kesukarelaan melakukan atau mengikuti perintah tanpa mengandung unsur-unsur pemaksaan dan intimidasi. Apabila keberhasilan tersebut mengandung unsur paksaan dan intimidasi, maka proses tersebut tidak lagi dilihat sebagai keberhasilan persuasi dalam upaya mempengaruhi namun mengarah pada koersi. Berbeda lagi jika keberhasilan persuasi yang dilakukan oleh individu satu ke individu lainnya mengandung unsur penyimpangan isi, kebenaran fakta serta bukti-bukti yang tidak jelas, maka proses tersebut juga tidak dipandang sebagai proses persuasi melainkan adanya praktik manipulasi.

\subsection{Proses dan model komunikasi antar pribadi}

Keberhasilan individu gay dalam memutuskan VCT serta pendampingan tidak terlepas dari proses komunikasi yang ada di dalamnya. Proses komunikasi tersebut yang akan menjadi titik perubahan cara berkomunikasi. Proses komunikasi yang baik adalah proses yang dapat diterima dan dapat berjalan tanpa adanya gangguan. Apabila dalam proses tersebut mengalami kendala, maka komunikasi yang akan disampaikan tidak dapat diterima dengan baik oleh penerimanya. Komunikasi menurut DeVito dalam (Liliweri, 2015: 53) merupakan proses atau tindakan mengalihkan pesan dari pengirim kepada penerima melalui saluran tertentu setelah melalui gangguan interferensi dengan salah satu elemen kunci dalam komunikasi yaitu adanya perubahan.

Proses komunikasi biasanya dimulai pada komunikasi antar personal yang meliputi beberapa tahapan pada model Mark Knapp, dalam (Liliweri, 2015: 54-58), diantaranya proses komuniakasi antarpersonal yang dilakukan secara langsung atau tatap muka. Hal tersebut 
dikarenakan pesan akan diterima secara jelas dan mudah dipahami oleh penerima tanpa adanya gangguan atau hambatan. Isi pesan yang akan disampaikan juga beragam sesuai bentuk pesan serta kebutuhannya. Proses komunikasi secara langsung akan terjadi saat dua orang bertemu pada waktu dan tempat yang sama, sehingga kecil kemungkinan terjadi hambatan maupun adanya kesalah pahaman dalam berkomunikasi.

Selain dilakukan secara langsung atau tatap muka, proses komunikasi antarpersonal juga dapat dilakukan dengan menggunakan perantara media seperti telephone maupun alat elektronik lainnya yang terhubung dengan jaringan internet. Kecanggihan teknologi saat ini memudahkan kita dalam melakukan berbagai aktifitas dengan orang lain tanpa harus bertemu saat itu juga. Melalui perantara media, kita dapat berkomunikasi tidak hanya menggunakan satu cara. Komunikasi melalui perantara media dapat mempergunakan telephone, tablet, laptop, komputer bahkan media lainnya yang berfungsi sebagai alat untuk berkomunikasi. Berbagai aplikasi yang digunakan sebagai pendukung komunikasipun beragam sesuai kebutuhan yang akan kita gunakan. Kelemahan dari proses komunikasi ini yaitu adanya gangguan cuaca, atau signal yang dapat memutuskan komunikasi sewaktu-waktu serta keterbatasan finansial setiap individu dalam penggunaan aplikasi berbayar tersebut. Penelitian ini akan melihat bagaimana proses komunikasi antarpersonal yang terjadi dengan cara tatap muka atau langsung maupun dengan perantara media.

\subsection{Relasi Homoseksual}

Relasi homoseksual merupakan hubungan romantis antara dua individu berjenis kelamin yang sama. Antropolog Gil Herdt mengklasifikasikan relasi homoseksual ke dalam empat model, yaitu: Age-Strtuctured Homosexsuality adalah lelaki berhubungan seks dengan lelaki yang lebih tua sebagai proses pendewasaan, Gender-Reserved Homosexsuality adalah lelaki yang berpakaian dan bertingkah laku seperti perempuan atau sebaliknya, Role-Specialized Homosexsuality adalah hubungan seks sesame jenis hanya diperbolehkan untuk peran atau status sosial tertentu, dan Modern-Gay Movement adalah homoseksual era modern dan orang tersebut mendeklarasikan diri sebagai seorang gay dan mengadopsi identitas tertentu (Yulius, 2015: 11).

Pengaplikasian relasi homoseksual pada penelitian ini, merujuk pada hubungan romantisme yang terjadi antara narasumber dengan pacar sesama LSL. Dalam penelitian ini adalah anggota Semarang GAY@ Community yang membina hubungan sejenis atau laki-laki suka laki-laki (LSL) yang akan berdampak pada hubungan intim diantara kedua belah pihak (sex). Peneliti akan mengamati apakah hubungan intim tersebut dilakukan dengan cara yang aman (memakai kondom) atau tidak sehingga penyebab peningkatan HIV/AIDS akibat hubungan seksual beresiko tinggi dapat terjawab melalui relasi homoseksual. 


\section{VCT (Voluntary, Counseling dan Tasting)}

VCT merupakan singkatan dari Voluntary, Counseling and Tasting. VCT merupakan kegiatan konseling yang menyediakan dukungan psikologis, informasi dan pengetahuan HIV dan AIDS, mencegah penularan HIV, mempromosikan perubahan perilaku yang bertanggung jawab, pengobatan ARV dan memastikan pemecahan berbagai masalah terkait dengan HIV dan AIDS. VCT yang berkualitas tinggi tidak saja membuat orang mempunyai akses terhadap berbagai layanan, tetapi juga efektif bagi pencegahan HIV. Layanan VCT dapat digunakan untuk mengubah perilaku beresiko dan memberikan informasi tentang pencegahan HIV dan AIDS (Kementrian Kesehatan RI, 2014: xv).

Pada penelitian ini, HIV/AIDS adalah penyakit yang dialami oleh anggota Semarang GAY@ Community yang dinyatakan positif. Sedangkan VCT merupakan tes yang dilakukan pada individu gay serta melakukan konseling secara sukarela saat sebelum melakukan tes atau sesudah melakukan tes pada anggota Semarang GAY@ Community. Peneliti akan melihat bagaimana proses komunikasi negosiasi untuk memutuskan melakukan VCT dengan cara sukarela.

\subsection{SGC (Semarang GAY@ Community)}

Salah satu komunitas yang membantu dalam menangnggulangi masalah peningkatan HIV/ AIDS pada kategori LSL adalah SGC atau Semarang GAY@ Community. Komunitas tersebut merupakan organisasi non pemerintah independen berbasis (gay dan LSL lainnya) yang didirikan oleh beberapa teman komunitas pada 16 Juni 2009 dan bersifat terbuka. SGC merupakan pengembangan kelompok komunitas GAY di kota Semarang yang sudah ada pada era tahun 80an bernama GAYa Semarangan yang sebelumnya sudah memiliki jaringan di kotakota lain khususnya di Pulau Jawa. Isu HIV/AIDS menjadi salah satu isu yang diangkat SGC diawal organisasi ini berdiri dan bekerja sama dengan salah satu lembaga donor Global Found (GF) sebagai implementing unit dengan SSR Yayasan Graha Mitra Semarang dalam penanggulangan HIV/AIDS pada kelompok LSL di delapan wilayah Jawa Tengah. Sebagai organisasi yang berbasis LSL tidaklah sukar bagi SGC yang melibatkan komunitas gay di Semarang dalam beragai program pemberdayaan pengendalian HIV dan penanganan AIDS.

Pemilihan Semarang GAY@ Community pada penelitian ini dikarenakan SGC adalah satu-satunya komunitas gay dan LSL yang terbuka di Kota Semarang. Pengurus serta anggota dari komunitas tersebut sering mengikuti seminar serta pelatihan yang terkait dengan kesehatan reproduksi serta isu HIV/AIDS. Anggota komunitas tersebut biasanya juga melakukan tes HIV/ AIDS secara rutin sebagai contoh dan mendukung gerakan hidup sehat. Selain itu, komunitas tersebut juga berupaya dalam pencegahan virus HIV/AIDS pada anggota yang dinyatakan negatif, serta pendampingan bagi individu gay yang dinyatakan positif tanpa membedakan latar belakang dari ODHA tersebut. 


\section{Metode Penelitian}

\subsection{Paradigma Penelitian}

Paradigma menurut Guba dan Lincoln adalah "the basic beliefs or worldview that guides the investigator, not only in choices of method but in ontologically \& epistemologically fundamental way", artinya adalah keyakinan dasar atau cara pandang terhadap dunia (Guba \& Lincoln, 1994). Penelitian ini menggunakan paradigma kontruktivisme untuk memandang realitas kehidupan sosial bukanlah realitas yang natural tetapi terbentuk dari hasil konstruksi dengan pendekatan fenomenologi sebagai metode penelitian. Fenomenologi cenderung digunakan dalam penelitian kualitatif sebagai landasan metodologisnya. Hal tersebut dikarenakan observasi, wawancara, dan telaah dokumen adalah metode yang paling mendasar untuk melakukan penelitian fenomenologi.

Fenomenologi menurut (Kuswarno, 2009: 1) merupakan aliran filsafat dan metode berpikir yang mempelajari fenomena manusiawi tanpa mempertanyakan penyebab fenomena, realitas objektif dan penampakan. Fenomena yang tampak merupakan objek dari makna transdental, oleh sebab itu untuk mendapatkan hakikat kebenaran kita harus memahami fenomena yang tampak. Tujuannya adalah mempelajari bagaimana fenomena dialami dalam kesadaran, pikiran, dan dalam tindakan sebagaimana fenomena tersebut bernilai atau diterima secara estetis. Secara ontologis, fenomenologi mempelajari sifat alami kesadaran dari individu karena akan dibawa ke dalam permasalahan mendasar jiwa dan raga (traditional mind-body problem). Bagi pengikut Husserl, persoalan jiwa raga ini dipecahkan dengan bracket ing method, yakni metode mempertanyakan eksistensi setiap hal yang ada di sekeliling kita. Secara epistemologi, fenomenologi membantu kita menemukan pengetahuan karena di dalam fenomeno-lah pengetahuan itu berada. Masih menurut Husserl, epistemologi dalam fenomenologi merupakan sarana untuk mencapai kebenaran dan pengetahuan. Dengan demikian, focus pada epistemologi adalah mengajak kepada persoalannya sendiri (Kuswarno, 2009: 30-31).

\subsection{Desain penelitian}

Penelitian ini berjenis kualitatif karena metode yang biasa digunakan dalam paradigma konstruktivisme adalah kualitatif. Metode kualitatif mempelajari tentang apa, siapa, dimana, kapan, mengapa, serta bagaimana yang berpedoman pada ilmu komunikasi Creswell. Dengan penelitian kualitatif semua permasalahan individu, termasuk didalammya komunitas gay, dapat dijawab atau dianalisis dengan sebaik-baiknya.

Menurut Moleong (2010 : 27), penekanan penelitian kualitatif berakar pada latar alamiah sebagai keutuhan, mengandalkan manusia sebagai alat penelitian, memanfaatkan metode kualitatif, analisis data secara induktif, mengarahkan sasaran penelitian pada usaha menemukan teori dari dasar, bersifat deskriptif, lebih meningkatkan proses daripada hasil, 
membatasi studi tentang fokus, memilih seperangkat kriteria untuk menulis keabsahan data, rancangan penelitian bersifat sementara serta hasil penelitian disepakati oleh peneliti dan subjek peneliti sehingga metode kualitatif dirasa tepat untuk digunakan sebagai cara memecahkan masalahan dari penelitian.

Metode kualitatif yang digunakan dalam penelitian ini adalah tipe desain deskriptif. Metode deskriptif digunakan pada penelitian ini untuk membuat deskripsi mengenai peningkatan kasus HIV/AIDS yang terjadi pada komunitas tersebut, bagaimana cara melakukan dan membujuk anggota untuk mau tes dan konseling, cara pencegahan serta sosialisasi virus tersebut serta deskripsi mengenai komunitas itu sendiri dengan menggunakan bahasa yang santun dan lugas secara sistematis sebagai gambaran mengenai berbagai fakta dan data sehingga dapat digunakan sebagai cerita serta adanya hubungan antara penelitian ini dengan fenomena yang terjadi.

\subsection{Situs Penelitian}

Situs penelitian ini dilakukan di wilayah Kota Semarang yang dibantu oleh LSM Semarang GAY@ Community yang beralamatkan di daerah Hos Cokroaminoto III/F2. Pemilihan wilayah dikarenakan Kota Semarang menjadi salah satu kota dengan tingkat penyebaran virus HIV dan AIDS tertinggi di Jawa Tengah.

\subsection{Teknik pengumpulan data}

Dalam penelitian ini, ada beberapa teknik pengumpulan data yang digunakan oleh penulis. Semakin banyak data yang diperoleh maka hasil penelitain akan semakin bagus, tetapi semakin sedikit data yang diperoleh maka perlu dilakukan pengkajian dalam pengumpulan data tersebut. Data-data yang dikumpulkan juga meurpakan data yang valid dan memiliki sumber yang jelas, karena sedikit kesalahan dalam pengumpulan data maka akan mempengaruhi hasil dari penelitian tersebut. Teknik pengumpulan data ynag digunakan dalam penelitian ini adalah: pertama studi pustaka atau studi literature menurut (Nazir, 1988: 112) merupakan sumber data sekunder yang diperlukan untuk mendukung penelitian serta sebagai masukan dalam mempelajari cara penulisan dan bahsa yang dipilih agar peneliti lebih kritis serta analitis dalam mengerjakan penelitian. Pada penelitian ini, studi pustaka digunakan untuk mengumupulkan data-data mengenai isu terkait serta menemukan proses komunikasi negosiasi melalui penelaahan, interpretasi serta generalisasi dari fakta-fakta yang ada pada komunitas tersebut. Kedua obsrvasi langsung yang menurut (Nazir, 1988: 212) merupakan teknik dalam penelitian berupa pengamatan yang dilakukan secara sistematik dan biasanya berkaitan dengan tujuan dari penelitain tersebut. Pengamatan tersebut untuk melihat realitas atau kejadian nyata yang dialami oleh informan. Pengamatan akan dilakukan secara langsung (partisipan) dengan tujuan mengurangi adanya sekat antara peneliti dengan yang diteliti 
serta dapat melihat kejadian nyata pada objek yang akan diteliti. Ketiga adalah dokumentasi yang merupakan teknik pengumpulan data melalui data tertulis atau image Semarang GAY@ Community yang ada hubungannya dengan masalah penelitian untuk mengisi atau menjawab pertanyaan dengan sebenar-benarnya yang dibuat oleh peneliti pada kertas yang disebut isntrumen penelitian. Pertanyaan-pertanyaan tersebut berisi tentang pengetahuan HIV/AIDS, proses negosiasi dalam pengambilan keputusan dalam memutuskan melakukan VCT. Selain itu, peneliti melakukan perekaman baik suara maupun gambar saat melakukan wawancara pada recorder atau handphone sebagai bukti bahwa penelitian telah dilaksanakan. Yang terakhir atau merupakan inti dari pengambilan data penelitian adalah wawancara mendalam (in-dept interview). Menggunakan teknik tersebut karena dalam wawancara mendalam, peneliti dan yang diteliti akan terbangun suatu kedekatan pribadi sehingga informasi yang diperlukan akan didapat sedetail mungkin. Wawancara menurut (Nazir, 1988: 234) merupakan proses percakapan secara langsung/tatap muka antara dua orang atau lebih dan berisi tanya jawab mengenai pertanyaan-pertanyaan seputar penelitian dengan menggunakan panduan wawancara (interview guide). Teknik ini digunakan untuk pengumpulan informasi dengan mengajukan pertanyaan secara lisan dan dijawab secara lisan pula dengan sebenar-benarnya, dalam sejumlah penelitian, pertanyaan ini diajukan kepada keenam narasumber.

\subsection{Analisis dan interpretasi data}

Penelititidak berusaha menganalisis tanda yang ditangkap dalam wawancara dengan responden, tetapi menganalisis setiap jawaban atau pertanyaan yang diungkapkan individu pada saat melakukan wawancara. Peneliti tidak berusaha untuk memahami komunikasi non verbal yang dilakukan oleh responden tetapi murni hanya pengalaman yang disadari responden, dengan kata lain komunikasi yang dilakukan secara spontan dan diamati sesuai subjektifitas peneliti. Teknik analisis data penelitian ini merujuk pada modifikasi teknik analisis fenomenologi dari Van Kaam (Moustakas, 1994: 121) yaitu: (1) Listing and Preliminary Grouping, (2) Reduction and Elimination, (3) Clustering and Thematizing the Invariant Constituent/ Thematic Potrayal, (4) Final Identification of the Invariant Constituents and Themes by Application: Validation, (5) Individual Textural Description, (6) Individual Structural Description, (7) Textural-Structural Description.

\subsection{Kualitas Data}

Kualitas data dalam penelitian kualitatif diperoleh dari keaslian akan kejadian nyata serta kredibilitas atau dapat dipercaya yang dikembangkan untuk penelitian dengan paradigma kontruktivisme. Kualitas data yang baik akan digunakan untuk penyelidikan yang dihasilkan berdasarkan asumsi keunikan dari penelitian ini. Penelitian dengan kriteria yang nyata akan menggambarkan suatu kebenaran serta keterbukaan dalam peristiwa yang terjadi. Dalam 
penelitian ini, peneliti tidak berfokus pada upaya melihat kesesuaian antara konsep yang abstrak dengan data empirik, namunlebih pada upaya untuk memberikan gambaran mengenai kehidupan sosial yangdialami oleh mereka yang menjadi subjek penelitian, contoh subjek pada penelitian ini adalah individu gay.

Kriteria data yang kedua adalah kredibilitas sebagai sumber informasi yang dapat dipercaya. Kredibilitas yang digunakan untuk memenuhi kriteria tersebut yaitu memilih individu gay serta ODHA pada suatu komunitas sebagai narasumber yang mengalami peristiwa tersebut secara nyata sehingga hasil yang didapatkan sesuai dengan keperluan penelitian. Peneliti juga tidak diperbolehkan untuk memberikan masukan saat berlangsungnya tanya-jawab karena dapat memberikan pengaruh terhadap informasi yang diberikan oleh narasumber.

\section{Hasil Penelitian dan Pembahasan}

\subsection{Deskripsi informan penelitian}

Dalam penelitian ini, informan penelitian adalah LSL yang tergabung dalam LSM Semarang GAY@ Community yang terdiri atas tiga orang LSL yang negatif HIV/AIDS dan tiga orang yang positif HIV/AIDS. Informan yang negatif HIV/AIDS yaitu: AL (23 tahun), FR (22 tahun), dan BD (30 tahun). Adapun tiga orang yang positif HIV/AIDS yaitu: LH (33 tahun), RH (26 tahun) dan SS (22 tahun).

\subsection{Proses komunikasi negosiasi individu gay dalam memutuskan melakukan VCT secara sukarela}

Proses komunikasi negosiasi dalam memutuskan VCT tanpa melalui perselisihan atau adu argumentasi. LSL terdorong rasa tanggung jawab terhadap diri sendiri yang pada akhirnya menghasilkan sikap sukarela.

Keenam narasumber pada penelitian ini menghasilkan gaya komunikasi yang berbeda-beda. Seperti gaya komunikasi karena jebakan/paksaan dari pihak keluarga menurut pengalaman narasumber positif, LH (33 tahun). Meski ada posisi tawar antara LH dengan salah satu anggota keluarganya, akhirnya LH memutuskan melakukan VCT karena merasa terdesak dengan keadaan. Narasumber positif, SS (22 tahun) mengaku memutuskan VCT karena adanya imbalan berupa uang transport. Bagi SS, adanya imbalan yang diterimanya setelah melakukan VCT merupakan bentuk timbal balik dari adanya proses negosiasi yang dapat menguntungkan kedua belah pihak. Dari adanya imbalan tersebut membentuk gaya komunikasi yang berbeda, sedangkan AL (23 tahun), FR (22 tahun), dan BD (30 tahun) mengaku memutuskan VCT karena penasaran terhadap status kesehatannya akibat faktor resiko sebagai LSL sehingga membentuk gaya komunikasi yang berbeda dari sebelum-sebelumnya.

Framing dalam penelitian ini, digunakan untuk menawarkan kepada LSL dalam upaya pencegahan HIV/AIDS melalui VCT yang dilaksanakan oleh Dinas Kesehatan layanan tes gratis 
dan layanan konseling secara sukarela serta berbagi informasi dengan individu gay dan belajar lebih banyak tentang mereka dan apa yang mereka inginkan.

Pada penelitian ini keenam narasumber mengaku melakukan konseling tentang HIV/ AIDS berkaitan dengan kondisi penyebaran HIV/AIDS, sebab-sebab, gejala, bahaya, penularan, pencegahan, dan pengobatan oleh konselor. Setelah dirasa cukup mendapatkan informasi, keenam narsumber melakukan posisi tawar sebagai bentuk kesediaanya mau melakukan tes secara sukarela yaitu dengan diambil darahnya. Proses negosiasi berjalan pada saat posisi tawar dimulai antara narasumber dan konselor secara verbal, sampai pada akhirnya narasumber mau memutuskan untuk melakukan tes. Sebelum diambil darahnya, narasumber diharuskan menandatangani sebuah perjanjian yang isinya adalah mau diambil darahnya untuk melakuakn tes dan bertanggung jawab atas hasil dari tes di kemudian hari. Hal itu merupakan bentuk kesepakatan negosiasi komunikasi yang dibuat antara narasumber dengan petugas kesehatan.

Dalam menyusun strategi, digunakan sebagai pesan yang disampaikan kepada LSL dan bertujuan agar LSL bersedia mengikuti tes dan konseling HIV/AIDS. Penyusunan pesan dalam proses negosiasi tersebut mengandung pesan persuasi sebagai upaya untuk membujuk individu gay yang berkaitan dengan program pengendalian HIV/AIDS untuk mencegah dan mengurangi penularan virus tersebut, meningkatkan kualitas hidup ODHA serta mengurangi dampak negatif pada tataran sosial dan ekonomi akibat HIV/AIDS terhadap individu gay, keluarga dan masyarakat. Pada tahapan ini, LSL menjadi paham dan mengetahui HIV/AIDS.

Selanjutnya, dalam mengelola hubungan antara LSL dengan Dinas Kesehatan yang menyediakan layanan tes gratis dan layanan konseling VCT, dilakukan melalui pendamping sebagai negosiator, terutama ODHA yang terkontrol. Pendampingan dilakukan dengan memberikan konseling tentang HIV/AIDS. Dalam proses negosiasi apabila sudah terjadi kesepakatan, maka akan ditandai dengan perjanjian baik secara tertulis maupun verbal seperti penandatangan kontrak atau jabat tangan untuk tes HIV/AIDS.

Bagi narsumber negatif, rutin melakukan VCT setiap 3 atau 6 bulan sekali sesuai anjuran konselor. Kegiatan VCT rutin dilakukannya sebagai upaya pencegahan penularan Infeksi Menular Seksual (IMS) serta penularan virus HIV/AIDS yang kian meningkat.

Proses komunikasi negosiasi pada penelitian ini membentuk konsep yang belum pernah ditemukan pada penelitian sebelumnya yaitu adanya negosiasi bertingkat pada proses negosiasi sebelum memutuskan melakukan VCT. Proses negosiasi pertama berlangsung saat keenam narsumber mendapatkan informasi dan ajakan melakukan VCT sebagai upaya pencegahan virus HIV/AIDS, narasumber mencoba menegosiasikan informasi tersebut dengan berbagai pertimbangan akibat adanya contoh nyata terhadap teman-teman sesama LSL yang sudah meninggal. Setelah memutuskan melakukan VCT, proses negosiasi berulang saat narsumber melakukan konseling karena saat konseling mereka dihadapkan pada sebuah kesepakatan untuk mau menandatangi perjanjian pengambilan darah tanpa adanya paksaan. 
Dari adanya kesepakatan tersebut terbentuk pula sebuah kesepakatan secara sukarela. Proses negosasi kembali berulang saat narsumber dihadapkan pada keputusan untuk mau melakukan VCT secara rutin setiap 3 hingga 6 bulan sekali. Dari adanya proses negosiasi yang dilakukan secara terus-menerus tersebut, terbentuklah proses komunikasi negosiasi berulang atau multilayer negotiation secara sukarela pada penelitian ini.

\subsection{Proses dan model komunikasi antar pribadi}

Proses komunikasi dalam penelitian ini menggunakan dua model yaitu, model komunikasi secara langsung atau tatap muka serta model komunikasi melalui media. $\mathrm{N}$ a $\mathrm{r}$ a $\mathrm{s} \mathrm{u} \mathrm{m}$ b e $\mathrm{r}$ negatif, AL (23 tahun), FR (22 tahun), dan BD (30 tahun) serta narsumber positif RH (26 tahun) mengaku awal mengetahui informasi tentang VCT dan mau melakukan VCT karena dirinya sering mendapatkan broadcast dari grup BBM, WA serta beranda facebook karena mereka merupakan anggota Semarang GAY@ Community, terlebih saat berkumpul dengan anggota di komunitasnya, mereka selalu dianjurkan untuk melakukan VCT rutin.

Berbeda dengan kedua narsumber positif yaitu LH (33 tahun) yang mengaku awal mengetahui informasi tentang VCT karena didapatkan secara langsung saat dirinya dijebak oleh kakak perempuannya karena mereka berada pada satu tempat dan waktu yang sama, sedangkan SS (22 tahun) di dapatkan melalui perantara media saja melalui BBM karena mereka merupakan pasangan LSL.

Adanya pesan persuasi yang kuat dengan intensitas yang sering secara langsung saat diantar LSL saling bertemu maupun melalui perantara media serta dorongan dari temanteman komunitas, membuat mereka secara sukarela mau melakukan VCT. Meski awal mau melakukan VCT ada ketakutan yang luar biasa di dalam diri, hal tersebut tidak membuat mereka patah semangat sampai membatalkan niat.

\section{Simpulan}

Peneguhan orientasi seksual yang berpengaruh pada adanya interaksi komunikasi (coming out) kepada sesama teman LSL untuk akhirnya menentukan pengambilan keputusan dari keenam narasumber pada penelitian ini termasuk dalam model Modern-Gay Movement yang menjelaskan hubungan romantisme antara dua individu berjenis kelamin sama yang mendeklarasikan diri sebagai seorang gay dengan mengadopsi identitas tertentu di era sekarang. Identitas tersebut digunakan untuk melakukan coming out kepada lingkungan terlebih sesama teman LSL untuk mencari pasangan sehingga mereka tidak secara sembunyi-sembunyi menunjukkan orientasi seksualnya. Selain itu, Modern-Gay Movement juga ditunjuukan sebagai pelabelan diri yang membedakan mereka sebagai posisi tawar dalam melakukan perilaku seksual beresiko dengan sesama jenisnya. Pelabelan tersebut dikategorikan menjadi tiga yaitu Top yang berperan sebagai lelaki saat melakukan hubungan, Both yang berperan 
sebagai perempuan saat melakukan hubungan dan Vers yang dapat berperan sebagai lelaki maupun perempuan tergantung permintaan dari pasangan seksual sesama jenisnya.

Seperti pernyataan Gil Herdt, Keenam narasumber memiliki hubungan romantisme dan mengadopsi model Modern-Gay Movement untuk menunjukkan jati diri dan orientasi seksualnya kepada teman-teman sesama LSL. Dengan adanya coming out kepada sesama menumbuhkan rasa saling menjaga sehingga mereka saling mengingatkan untuk selalu berhatihati terhadap perilaku seksual beresiko dengan salah satu cara memberikan informasi terkait HIV/AIDS dan ajakan melakukan VCT.

Komunikasi antarpribadi sangat berperan pada proses negosiasi karena memiliki dua fungsi utama yaitu fungsi sosial dan fungsi pengambilan keputusan. Pada penelitian ini, komunikasi antarpribadi yang digunakan pada proses negosiasi difokuskan pada fungsi pengambilan keputusan karena dapat digunakan sebagai pengaruh dari individu gay untuk melakukan VCT. Fungsi pengambilan keputusan dapat terjadi karena adanya informasi yang dibagikan. Informasi merupakan kunci utama dalam pengambilan keputusan yang efektif, karena pada proses negosiasi menghendaki adanya sebuah keputusan yang mengarah pada persetujan bersama. Untuk mencapai persetujuan, masing-masing pihak memberi dan menerima saat kondisi transaksi sebenarnya telah disepakati, namun perlu diingat bahwa sebelum terjadinya kesepakatan, ada sebuah elemen persuasi yang bersifat mempengaruhi pada proses negosiasi untuk memberi pesan kepada masing-masing pihak.

Proses komunikasi negosiasi pada individu gay dalam memutuskan VCT menghasilkan sikap sukarela dari individu gay sendiri karena terdorong oleh rasa tanggung jawab terhadap diri sendiri. Selain itu, LSL mendapat ajakan dan saran dari teman, keluarga, dan pendamping karena komunikasi yang terjalin antara narasumber dengan orang tersebut sangat berperan dalam mendorong narasumber mau memutuskan melakukan konseling dan tes terbilang intens.

Framing yang pada proses komunikasi negosiasi digunakan untuk memahami situasi serta membuat posisi tawar. Dalam penelitian ini, framing digunakan untuk menawarkan kepada individu gay dalam upaya pencegahan HIV/AIDS melalui tes VCT yang dilaksanakan oleh Dinas Kesehatan layanan tes gratis dan layanan konseling CST (Care Support Treatment) secara sukarela serta berbagi informasi dengan individu gay dan belajar lebih banyak tentang mereka dan apa yang mereka inginkan. Pada penelitian ini, keenam narasumber mengaku sebelumnya tidak pernah mengetahui fungsi dari VCT secara penuh sebagai upaya pencegahan HIV/AIDS yang ditawarkan oleh Dinas Kesehatan Kota Semarang. Melalui perantara keluarga, teman maupun pacar, sesuai dengan pengalaman masing-masing narasumber, akhirnya mereka mengetahui keberadaan dari VCT tersebut dan mencoba memikirkan kesehatan diri dengan melakukan VCT secara sukarela. Framing digunakan sebagai proses awal keenam narasumber untuk mencoba melakukan negosiasi. 
Proses yang kedua yaitu menyusun strategi yang digunakan sebagai pesan yang akan disampaikan dan memiliki tujuan agar pesan tersebut dapat dijalankan sesuai perintah. Penyusunan pesan dalam proses negosiasi tersebut mengandung pesan persuasi sebagai upaya untuk membujuk individu gay yang berkaitan dengan program pengendalian HIV/AIDS untuk mencegah dan mengurangi penularan virus tersebut, meningkatkan kualitas hidup ODHA serta mengurangi dampak negatif pada tataran sosial dan ekonomi akibat HIV/AIDS terhadap individu gay, keluarga dan masyarakat. Pada penelitian ini, keenam narsumber mengaku diajak baik oleh keluarga, teman, pacar maupun konselor untuk melakukan VCT dan VCT rutin. Saat proses penyusunan strategi yang dilakukan oleh keluarga, teman, pacar maupun konselor kepada keenam narasumber, mereka mengaku memiliki pengalaman yang berbeda-beda sebagai tahapan untuk menegosiasikan keputusannya. Bujukan tersebut ada yang ditanggapi secara langsung maupun adanya penolakan sebelumnya sebagai proses negosiasi, hingga akhirnya narasumber mencoba untuk mengambil sebuah keputusan. Selain itu, pada proses konseling, bujukan oleh konselor juga berfungsi dalam menyusun strategi yang dapat mempengaruhi individu gay dalam mengambil keputusan secara sukarela sebagai proses negosiasi. Bujukan yang dilakukan konselor pada tahap awal yaitu membangun kedekatan dengan keenam narasumber untuk memberikan pemahaman serta informasi terkait HIV/AIDS serta contoh maupun akibat yang dapat mengancam kelangsungan hidup individu gay akibat perilaku seksual beresiko. Setelah kedekatan yang terbangun diantara konselor dan narasumber saat melakukan konseling, barulah konselor mencoba mennggali informasi lebih dalam terkait identitas pribadi dan faktor resiko, sambil diselipkan edukasi terkait virus HIV/AIDS dan mempersuasi narasumber yang dinyatakan negative untuk segera melakukan VCT maupun VCT rutin serta yang dinyatakan positif untuk segera dilakukan pengobatan dan pendampingan.

Yang ketiga adalah mengelola hubungan, yaitu proses negosiasi antara negosiator dengan agen. Negosiator yang berperan dalam penelitian ini adalah adalah tenaga medis terkait, sedangkan agen adalah individu gay maupun ODHA. Dalam proses negosiasi apabila sudah terjadi kesepakatan, maka akan ditandai dengan perjanjian baik secara tertulis maupun verbal seperti penandatangan kontrak atau jabat tangan. Pada penelitian ini, perjanjian melakukan VCT baik saat awal maupun rutin dilakukan dengan mengatakan iya baik secara langsung maupun melalui perantara media terhadap negosiator, dalam hal ini narasumber (agen) dan yang mengajak (negosiator). Yang kedua saat melakukan VCT, narasumber yang berperan sebagai agen menandatangi formulir persetujuan secara seukarela yang diberikan oleh negosiator dalam hal ini petugas pelayanan maupun konselor untuk mau diambil darahnya guna pengecekan adanya virus HIV/AIDS di dalam tubuh masing-masing narasumber setelah melakukan konseling dengan konselor di tempat pelayanan, sedangkan bagi ODHA yang berperan sebagai agen saat akan melakukan terapi ARV ditandai dengan kesediaannya 
dalam pengambilan obat secara rutin setiap satu bulan sekali, serta untuk melakukan KDS dan pendampingan ditandai dengan perjanjian baik secara verbal saat mereka bertemu maupun melalui perantara media yaitu BBM dan whatsapp. Ketiga narasumber positif dalam penelitian ini mengaku, melakukan perjanjian kepada pendamping maupun kosnelor yang bertugas sebagai negosiator, melalui perantara media untuk mengikuti KDS dan pendampingan karena saat bertemu, mereka mengaku tidak langsung mengatakan "iya atau mau" karena adanya hambatan dari dalam diri dan lingkungan terhadap status baru sebagai ODHA.

Pada tahap ini, prsoses negosiasi untuk memahami situasi dimulai dari tahap sumber informasi terkait HIV/AIDS dan VCT melalui dua model komunikasi, baik yang didapatkan secara langsung maupun melalui perantara media. Setelah adanya sumber informasi yang dapat mempengaruhi narasumber, masuk pada proses negosiasi yang didalamnya terdapat elemen persuasi dalam mempengaruhi narasumber untuk melakukan kompromi sebelum mengambil keputusan secara sukarela. Proses negosiasi terbagi menjadi tiga tahapan.

Setelah melewati proses negosiasi, keenam narasumber mencoba merealisasikan dalam bentuk pengambilan keputusan. Pengambilan keputusan tersebut didasari oleh adanya informasi yang berasal dari dalam maupun luar dengan diimbangi dengan tambahan fakta untuk lebih meyakinkan. Informasi yang didapatkan tentunya berisi kebenaran tanpa ada intimidasi maupun diskriminasi sehingga dalam proses pengambilan keputusan dapat dilakukan secara suakrela. Setiap proses tahapan selalu mengandung pesan persuasi, sehingga pada penelitian ini, persuasi menjadi elemen penting dalam mempengaruhi individu gay tanpa adanya paksaan dan intimidasi.

Pada penelitian ini, setelah proses komunikasi negosiasi pada keenam narasumber berlangsung, maka dapat dilanjutkan dalam pengambilan keputusan untuk mau melakukan VCT dan rutin VCT secara sukarela. Setelah proses komunikasi negosiasi pada individu gay berjalan, keenam narasumber mengaku memutuskan apa yang terbaik bagi diri sendiri dan lingkungan terhadap perilaku seksual beresiko yang dijalaninya. Proses pengambilan keputusan bagi narasumber negatif yaitu berawal dari keputusan mengikuti rangkaian VCT. Rangkaian tersebut berupa konseling yang dilakukan antara negosiator (konselor, dan dokter) secara langsung saat melakukan VCT di tempat pelayanan kesehatan baik puskesmas maupun mobile VCT.

Pada pengambilan keputusan terbagi menjadi beberapa tahap yaitu tahap pertama adalah konseling sebelum tes dengan tujuan untuk memberikan edukasi bagi narsumber. Konseling pada penelitian ini merupakan tahap terpenting pada proses negosiasi karena pada tahap konselinglah keenam narsumber akan menentukan keputusannya. Konseling dimulai sejak narasumber mengaku telah mendapatkan ajakan melakukan VCT. Konseling tersebut dilakukan dengan sesama teman LSL baik secara langsung maupun melalui perantara media. Konseling dengan sesama teman LSL tersebut terkait bahaya penularan, bagaimana cara mengobati, biaya yang diperlukan saat VCT, bagaimana rangkaian VCT bahkan manfaat dari 
VCT. Setelah tahap konseling awal dengan sesama teman LSL sebelum memutuskan melakukan VCT, narasumber mengaku melakukan rangkaian konseling kembali saat memutuskan mengikuti rangkaian VCT. Konseling yang dirasakan keenam narsumberpun berbeda-beda, ada yang mengaku saat konseling dalam keadaan tegang karena ketakutan akan hasilnya, ada yang mengaku tidak nyaman karena konselornya seorang wanita, ada yang saat konseling digunakan untuk melakukan coming out dengan lingkungan sekitar, ada pula yang saat konseling mengaku bersikap biasa saja karena sudah yakin akan keputusannya. Sehingga pada temuan tersebut, konseling dirasa penting pada proses negosiasi untuk lebih memantapkan diri dan memiliki keberanian melawan hambatan-hamnbatan yang ada untuk akhirnya memutuskan tes. Konseling pada penelitian ini dibagi menjadi dua yaitu saat awal sebelum memutuskan tes, serta setelah melakukan tes.

Konseling kedua dilakukan saat mengikuti rangkaian VCT yang dilakukan secara langsung dengan konselor sehingga narsumber juga dapat mengetahui bagaimana sikap konselor saat itu. Masuk pada tahap kedua yaitu tes yang dimana narsumber harus melakukan perjanjian dengan cara menandatangi formulir persetujuan untuk diambil darahnya. Form tersebut merupakan bentuk dari kesepakatan diantara kedua belah pihak dalam bentuk tertulis sehingga tidak adanya paksaan dan harus dilakukan secara sukarela. Dengan adanaya penandatanganan formulir perjanjian maka proses negosiasi dalam pengambilan keputusan dapat dikatakan berhasil. Setelah dilakukan VCT, narasumber dihadapkan pada berbagai persoalan dan pilhan diantaranya pilihan untuk melakukan konseling rutin baik yang dilakukan secara langsung maupun melalui perantara media, pilihan melakukan VCT rutin, pilihan merubah perilaku seksual beresiko dengan tidak bergonta-ganti pasangan dan memakai pengaman saat berhubungan dan pilihan untuk mengajak teman LSL lain mengikuti jejak mereka untuk mau melakukan VCT meskipun tetap adanya penolakan maupun penerimaan dari pihak yang diajak. Disini peran narasumber tidak lagi menjadi agen melainkan berubah menjadi negosiator yang dapat mempengaruhi dan mempersuasi teman LSL lain yang berlaku sebagai agen dalam memutuskan VCT. Sedangkan bagi narasumber yang pada hasil tes dinyatakan positif dihadapkan pada pilihan untuk melakukan terapi ARV, KDS dan pendampingan. Pesoalan yang dimunculkan pada saat pengambilan keputusan berupa adanya hambatan baik secara internal (dari dalam) maupun eksternal (dari luar) serta persoalan bagaimana dan kepada siapa hasil tes tersebut akan disampaikan. Ketiga narasumber yang dinyatakan positif, tidak mau terbuka kepada lingkungan sekitar akan virus HIV/AIDS karena takut terhadap stigma serta adanya diskriminasi dari masyarakat, yang dapat menyatakan sudah "gay" juga "ODHA". Mereka lebih terbuka terhadap keluarga karena keluarga lebih dapat menerima apapun keadaanya, selian lebih sering berkomunikasi dengan keluarga dari pada lingkungan sekitar. 
Proses negosiasi pada penelitian ini tidak hanya dilakukan sekali, tetapi harus dilakukan secara berulang-ulang (multilayernegotiation) karena proses tersebut berasal dari dorongan diri sendiri, teman-teman terdekat, pacar, keluarga maupun orang-orang disekitarnya. Selanjutnya karena adanya dorongan tersebut membuat mereka memutuskan melakukan konseling. Keputusan sebelum melakukan konseling juga memerlukan negosiasi baik yang dilakukan pada level keluarga, sesama teman atau pacar LSL maupun orang-orang disekitarnya, hingga pada saat konseling mereka juga melakukan proses negosiasi sebelum akhirnya memutuskan untuk melakukan tes. Konseling juga merupakan proses yang krusial karena merupakan tahap penentu bagi individu gay untuk mau melakukan tes.

Komunikasi persuasi pada penelitian ini sebagai elemen pada proses negosiasi dikatakan berhasil karena informasi pesan yang disampaikan baik secara langsung maupun tidak langsung dapat dipahami oleh penerima pesan tanpa adanya hambatan sehingga berguna dalam mempengaruhi sikap. Pada proses pengiriman pesan dan informasi, penerima pesan akan menegosiasikan pesan tersebut untuk digunakan sebagai pertimbangan dalam pengambilan keputusan. Informasi merupakan kunci untuk mempertimbangkan berbagai hal yang dapat mempengaruhi pandangan seseorang sebelum menentukan sikap, sehingga untuk mencapai keberhasilan dalam mempengaruhi seseorang, informasi yang baik diperlukan agar pesan persuasi dapat disampaikan secara tepat.

Pada penelitian ini, pesan informasi terkait bahaya dan penularan HIV/AIDS yang disampaikan oleh keluarga, teman, pacar, petugas kesehatan yang dalam hal ini disebut negosiator kepada agen yang berperan sebagai individu gay menjadi penting sebagai proses menegosiasikan diri dalam memutuskan melakukan VCT. Kita harus menggunakan prinsipprinsip komunikasi yang efektif pada proses negosiasi dengan tujuan agar ide dan gagasan dapat diterima oleh pihak lawan dan mencapai sebuah kesepakatan.

Oleh karena itu, proses negosiasi melibatkan persuasi dan kompromi. Pada penelitian ini, paparan informasi yang diberikan dapat mempengaruhi individu gay untuk melakukan kompromi dengan pihak lawan yang mengajak, sehingga individu gay berusaha untuk menegosiasikan paparan informasi dan pesan persuasi tersebut menjadi sebuah keputusan yaitu melakukan VCT maupun rutin VCT.

Pada penelitian ini, peneliti memperoleh model komunikasi persuasi dalam negosiasi secara sederhana untuk menjelaskan komunikasi negosiasi individu gay dalam memutuskan VCT secara seukarela. Model tersebut merupakan objek persuasi berupa kepercayaan, tindakan, dan lain-lain, dengan tujuan untuk meyakinkan khalayak tentang informasi yang didapat yang bertujuan mempersuasi. Tujuannya harus membentuk pikiran khalayak hubungan antara tujuan dengan faktor motivasi. Pernyataan yang tegas untuk meyakinkan khalayak harus di dukung dengan adanya fakta agar khalayak percaya dan mencoba menegosiasikan tujuan tersebut agar mencapai sebuah keputuan. Gary Cronhike memperkenalkan macam- 
macam argument yang cenderung membentuk hubungan antara faktor motivasi dengan objek persuasi, salah satunya adalah hubungan saling mendukung. Hubungan tersebut melibatkan asosiasi dari objek persuasi terhadap sumber prestisius seperti pada penelitian ini. Model komunikasi persuasi dalam negosiasi secara sederhana pada penelitian ini dapat digambarkan dibawah ini.

Gambar dibawah menjelaskan bahwa persuasi dan hubungan merupakan elemen penting di dalam proses negosasi. Gambar tersebut didapatkan melalui data yang ada di lapangan sesuai dengan pengalaman dari keenam narasumber saat akan memutuskan melakukan VCT dan dilanjutkan dengan maupun rutin VCT secara sukarela sesuai kesadaran dari narsumber. Informasi terkait bahaya HIV/AIDS merupakan pesan persuasi yang disampaikan oleh negosiator kepada individu gay. Pesan persuasi tersebut di pertegas dengan fakta yang ada bahwa banyak teman-teman LSL yang terkena virus HIV/AIDS akibat perilaku seksual beresiko. Bahaya tersebut terus mengancam kelangsungan hidup individu gay yang akhirnya mereka berusaha menegosiasikan pesan tersebut. Paparan informasi yang diberikan dapat mempengaruhi individu gay sebagai memotivasi, selain itu diperkuat dengan adanya dorongan dan ajakan dari sesama teman LSL untuk mencegah penularan HIV/AIDS dengan melakukan VCT dan tetap rutin melakukan VCT, sehingga jaringan pertemanan yang terbangun merupakan kunci utama individu gay akan memutuskan melakukan VCT atau tidak. Pada proses negosiasi penelitian ini, kunci utamanya yaitu adanya networking pertemanan (hubungan) yang dapat mempengaruhi individu gay memutuskan VCT karena adanya pesan persuasi dan informasi yang diperjelas dengan tambahan fakta terkait bahaya virus HIV/AIDS dan teman-teman ODHA yang sudah meninggal.

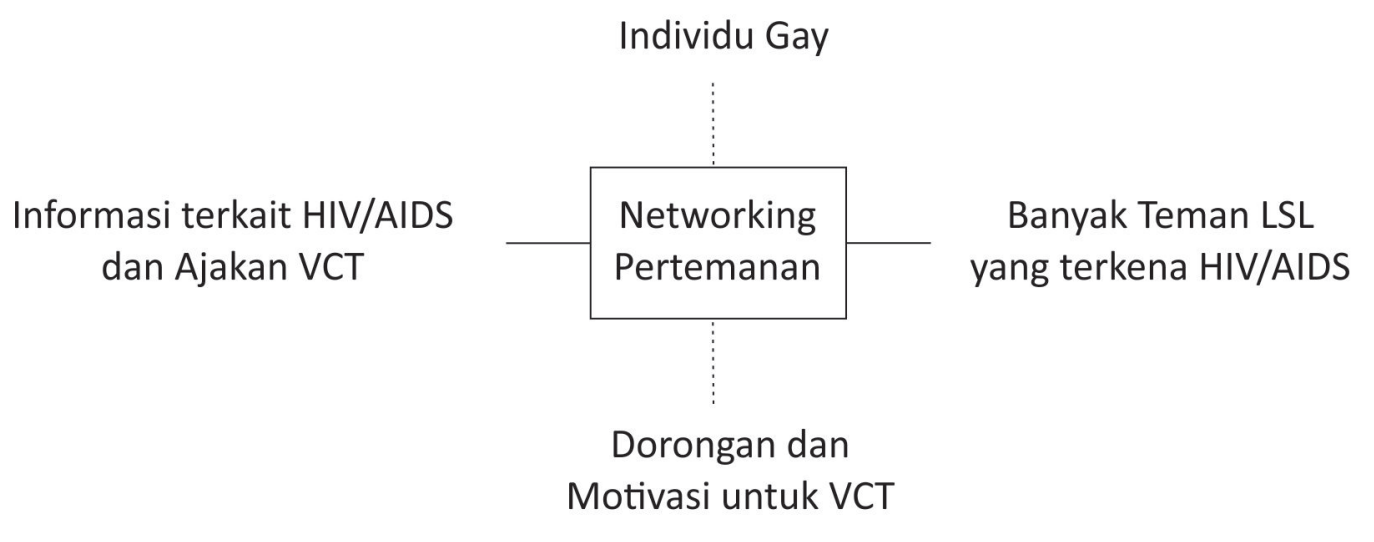

Gambar 1

Pola Komunikasi Persuasi pada Proses Negosiasi Individu Gay akan Memutuskan Melakukan VCT Secara SUkarela 
Setelah melakukan VCT awal, narasumber mengaku memiliki perasaan senasib dan sepenanggungan terhadap teman-teman sesama LSL untuk saling mengingatkan dan menjaga kesehatan diri dan lingkungan, oleh sebab itu, narasumber mengaku untuk menularkan informasi terkait HIV/AIDS kepada sesama LSL. Selain itu mereka juga mengaku untuk mengajak LSL lain melakukan VCT baik yang dilakukan secara langsung pada saat mereka bertemu di acara-acara komunitas gay. Ajakan untuk melakukan VCT sering mereka gaungkan melalui edukasi-edukasi pada saat acara yang dibuat oleh komunitas berlangsung. Sedangkan ajakan melalui perantara media juga mereka lakukan menggunakan BBM/WA. Ajakan melalui BBM/ WA bisa digunakan saat menjapri maupun melakukan pesan siaran untuk selalu mengingatkan sesama LSL melakukan VCT dan rutin VCT.

Tidak hanya mengajak untuk VCT bagi sesama LSL, narasumber juga mengaku sering diajak dan diingatkan untuk melakukan rutin VCT baik yang dilakukan oleh teman maupun pacar. Model komunikasi yang digunakan saat narasumber diajak untuk rutin VCT menggunakan dua model yaitu secara langsung saat mereka bertemu maupun melalui perantara media seperti BBM, WA, SMS dan telephone. Saat narasumber mengajak LSL lain melakukan VCT dan rutin, peran narasumber pada penelitian ini sebagai negosiator dan LSL lain sebagai agen, sedangkan saat narasumber diajak dan diingatkan untuk melakukan VCT dan rutin VCT baik pada level keluarga, teman dan pacar sesama LSL maka posisinya berkebalikan.

\section{Saran}

Pada penelitian ini menghasilkan proses komunikasi negosiasi bertingkat atau multilayer negotiation akan tetapi peneliti belum mendapatkan jawaban secara lengkap pada tahap negosiasi tingkat apa infomasi ajakan tersebut dapat mempengaruhi pengambilan keputusan melakukan VCT sehingga perlu digali lagi informasi lebih dalam terhadap LSL terkait tingkatan proses negosiasi dalam memutuskan melakukan VCT secara sukarela serta hubungan seperti apa yang terbentuk pada sesama LSL sehingga dapat berpengaruh dalam pengambilan keputusan melakukan VCT.

\section{Daftar Pustaka}

Jackman, Ann. 2004. How To Negotiate Teknik Sukses Bernegosiasi; Jadilah Negosiator Ulung dan Raihlah Win-Win Solution. Jakarta: Penerbit Erlangga

Kuswarno, Engkus. 2009. Fenomenologi Metode Penelitian Komunikasi. Bandung: Widya Padjajaran

Liliweri, Alo. 2015. Komunikasi Antar-Personal. Jakarta: Kencana.

Littlejohn, Stephen., W and Foss, Karen A. 2009. Encyclopedia Communication of Theory. SAGE Publications, Inc. 2455 Teller Road Thousand Oaks, California 91320

Moh., Nazir. 1999. Metode Penelitian Cetakan ke 3. Jakarta: Ghalia Indonesia 
Moustakas, Clark. 1994. Phenomenological Research Methods. London New Delhi: Sage Publications.

Moustakas, Clark. 1994. Phenomenological Research Methods. California: Sage Publications. Moleong, J., Lexy. 2010. Metologi Penelitian Kualitatif. Bandung: Rosdakarya.

Smith, Ronald., D. 2013. Strategic Planning for Public Relations $4^{\text {th }}$ Edition. New York: Routledge Taylor and Francis Group

Spoelstra, Manie and Pienaar, Wynand. 1996. Negotiation Theories, Strategies, and Skills Second Edition. Juta. Co. Ltd

Yulius, Hendri. 2015. Coming Out. Jakarta: Kepustakaan Populer Gramedia

\section{Jurnal IImiah}

Gary W. Dowsett. Researching Gay Men's Health: The Promise of Qualitative Methodology Sanusi, Sri Rahayu. 2014. Mobilitas Penduduk Usia Produktif dan Penyebaran HIV/ AIDS di Inodnesia Tahun 2013. Jakarta: Direktorat Analisis Dampak Kependudukan, BKBN

Theo Lorenc, Isaac Marrero-Guillamo'n, Alexis Llewellyn, Peter Aggleton, Chris Cooper, Angela Lehmann and Catriona Lindsay. Published on 20 Oktober 2016. HIV testing among men who have sex with men (MSM): systematic review of qualitative evidence. Published by oxfordjournals.org.

Victoria Kathrine Dale Blackwell-Hardie. 2009. A Qualitative Analysis of Factors Contributing to Increased HIV Incidence for Gay and Biseksual Men: Implications for Prevention. Department of Adult Education and Counselling Psychology Ontario Institute for Studies in Education University of Toronto

\section{Website}

Dinas Kesehatan Kota Semarang. 2016. Analisis Situasi IMS, HIV, dan AIDS Bulan Juni Tahun 2016. Semarang: Dinas Kesehatan Kota Semarang diunduh pada 15 September 2016 pukul 11.04

Jateng.tribunnews.com/2016/01/15/remaja-menjadi-populasi-tertinggi-hivaids-jateng diunduh pada 15 Sepetember 2016 pukul 14.22

Kementrian Kesehatan Republik Indonesia. 2014. Profil Kesehatan Indonesia Tahun 2013. Jakarta: Kementrian Kesehatan Republik Indonesia diunduh pada 15 September 2016 pukul 15.32

\section{Media Cetak}

Modesta Fiska, Zakki Amali, Muhammad Syukron, Royce Wijaya. (2016, 6 Oktober). Rubrik telisik. Suara Merdeka, halaman 19. 